This PDF is a simplified version of the original article published in Internet Archaeology. All links also go to the online version.

Please cite this as: Bisták, P. et al. 2021 Archaeological Digital Archiving in Heritage Management in Slovakia, Internet Archaeology 58. https://doi.org/10.11141/ia.58.16

\title{
Archaeological Digital Archiving in Heritage Management in Slovakia
}

Peter Bisták, Ján Zachar, Alexandra Rášová, Tibor Lieskovský, Ivica Kravjanská, Martina Orosová, Kristína Kročková and Michal Felcan

\section{Summary}

The Monuments Board of the Slovak Republic (MB SR) and the Regional Monuments Boards have been the state administrators of the cultural heritage, including archaeology, since 2002. This article aims to map the current state of archaeological digital archives within MB SR and eight Regional Monuments Boards, as well as present the usage and management of digital datasets within ongoing projects. The central archive of the MB SR maintains historical plans and cultural heritage documentation, created since the 1920s and continuously digitised (the collections of negatives, diapositives, projects, plans, schematic maps, and fieldwork documentation). Since 2012, MB SR has taken part in the Digital Monuments Fund project. Within this project, 2D and $3 \mathrm{D}$ documentation of a great number of cultural monuments has been created. In 2019 the implementation phase of the Monuments information system (PAMIS) project started. Its basic modules are the presentation layer, the knowledge agenda and state administration. There are several features in preparation within these modules, such as: updating; collection, consolidation and GIS processing of archaeological site data that belong to the monuments fund, including data from aerial laser scanning; the archaeological excavation registry and the archive of fieldwork reports; the registry of finds in the administration of MB SR; the electronic processing of the state administration activity within the protection of the archaeological cultural heritage. The PAMIS project will provide processed data and make them accessible to the state and public administration, owners of monuments, as well as to professionals and the general public, using online solutions (web GIS) with various approaches according to defined user roles. 


\section{Introduction}

Nowadays, information is usually digital. However, due to the nature of archaeology and cultural heritage, there is a lot of information from the past that is still stored in an analogue form. The digital age calls for the transformation from the analogue to the digital form - not only of the records and archives, but also of the workflows, processes and interpretation of the data, their storage, management, usage, and publishing.

At present, archaeological archives in Slovakia are managed by two institutions: the Institute of Archaeology of the Slovak Academy of Sciences (IA SAS) and the Monuments Board of the Slovak Republic (MB SR). Until 2002, the IA SAS managed archaeological sites, excavations and surveys, while the Institute of Monuments dealt with the cultural monuments, including a few hundred archaeological sites. In 2002, the Institute of Monuments was transformed by the legislation on the protection of monuments and historic sites into MB SR. MB SR, along with eight Regional Monuments Boards, administers the cultural heritage, including archaeology (Act No. 49/2002).

In this article, we provide an overview of cultural heritage management in Slovakia. We focus on the organisation of archaeological fieldwork in Slovakia and associated registers as well as the extensive agenda related to data, the management of monuments, archaeological sites and finds. We also discuss challenges and open questions related to monument protection and archaeological data management in Slovakia.

\section{Organisation of Archaeological Fieldwork in Slovakia}

To comprehend the current state of play relating to the organisation of archaeological fieldwork in Slovakia, we have to look a few decades back in time. Until 1989, archaeological fieldwork was carried out mainly by IA SAS and other state institutions, universities and museums. In addition to this, IA SAS also supervised fieldwork activities through so-called field commission and, to some extent, managed the financing. In the 1990s, after the socio-political changes caused by the fall of communism in 1989, the state ceased to finance archaeological fieldwork, while private construction activities were continually increasing. Archaeological cultural heritage could not be protected effectively in these conditions by existing institutions, thereby necessitating a substantial change in the way that archaeology was undertaken in Slovakia.

In 2002, this change was brought by Act No. 49/2002 on monument fund protection. As a result, MB SR was established as a specialised state administration body covering monument fund protection, along with eight Regional Monument Boards (for the sake of clarity, we will not address the division of powers between MB SR and Regional Monument Boards here). Apart from other issues, the new legislation focused on rescue archaeology with regard to construction activities: developers are now obliged by law to bear the costs of archaeological fieldwork. By introducing an archaeological licence, the new legislation has also enabled private archaeological companies to conduct fieldwork. The licence is issued by the Ministry of Culture of the Slovak Republic to organisations or individuals after fulfilling defined conditions (Mařik and Prášek 2014; Ruttkay et 
al. 2016). The licence for individuals is valid for five years. Among the licensed entities are state institutions (IA SAS, state museums), public institutions (universities, regional museums), private companies, and non-profit organisations. At present, overall there are 44 licensed organisations, employing 140 licensed archaeologists.

Under the 2002 legislation, MB SR also gained some competencies with regard to the management, monitoring, and inspection of archaeological fieldwork. In particular, MB SR: i) decides whether archaeological fieldwork is necessary during construction, ii) obliges the developer to contract a licensed archaeological body to carry out rescue fieldwork, iii) specifies the requirements of the fieldwork and checks their fulfillment, iv) acts as a central repository of fieldwork documentations and checks their compliance with the legal norms. The licensed archaeological bodies may also request approval to conduct fieldwork for scientific purposes, though this only represents about $5 \%$ of all archaeological fieldwork in Slovakia. The overwhelming majority, about 95\%, is rescue archaeology.

The 2002 legislation did not regulate finds deposition until 2009. It was assumed that the regional museums would collect all finds; however, they often did not have sufficient capacity and refused to take finds from private companies. In 2009, MB SR gained new powers to administer archaeological finds, which are the property of the Slovak Republic. Nonetheless, MB SR was not able to establish a depository of archaeological finds until 2017. The depository, in which MB SR manages the finds from fieldwork conducted by private and public companies, was opened in 2020 (Kmet'ová and Bisták 2020). Until this time, MB SR accepted archaeological finds only under special circumstances, for instance, when a private company was dissolved.

\section{Documentation and Registers of Archaeological Fieldwork}

The licensed archaeological bodies are required to summarise fieldwork results in their final report. This report has to contain a description of the fieldwork, findings and results (including graphic outputs and photographs), geodetic survey, cartographic outputs, and, if needed, expert opinions. It is submitted to MB SR both in paper and digital form. MB SR archives documentation for state administration; however, they are also archived by IA SAS for the management of the Central Register of Archaeological Sites of the Slovak Republic (CEANS). The licensed archaeological bodies are not required to archive their own activities.

At present, MB SR registers over 6000 final excavation reports as well as reports from non-destructive archaeological fieldwork conducted after 2002. MB SR and the eight Regional Monument Boards use their own registers: unfortunately, there is no central database. This issue is currently being addressed by the development of the Monument Information System (PAMIS, see Section 5).

In theory, final reports submitted to MB SR form part of the administrative files for ten years and after this time the archive should be made accessible to researchers. In practice, the entire process of transmission of the administrative files from the Regional Monument Boards is behind schedule and the archive is incomplete. 
In addition to archiving archaeological fieldwork reports, MB SR is the founder of a public specialisMonument Archiveed archive for monument protection in Slovakia. The Monument Archive manages about 3000 linear metres of archive documents - written, image, graphic, and film records. Since 2006, these records have been systematically digitised. Examples of digitisation projects include the entire collection of large slides $(10,000+$ images $)$, the collection of schematic plans $(5000+$ records), documents about medieval churches from Vclav Mencl (1905-1978, one of the pioneers of monument care in Slovakia), plans and graphics from 1919-51, or the ongoing digitisation of the photographs of the city of Banská Bystrica and the files from the State Department of Monuments protection dating from 1919-39.

The archive documents also include records concerning archaeological heritage protection, from the establishment of the first Slovak monument authorities in 1919 to the present day and copies of records of the Hungarian Monuments Commission (18721918). In the archive, there are also archaeological excavation records with graphic documentation, photographs, negatives and diapositives for projects that were conducted by various monument protection bodies before 2002. Up to the present day, about $30 \%$ of all archive documents concerning archaeology have been digitised.

Apart from MB SR, IA SAS is another institution with a central register of archaeological fieldwork. Until 2002, it was the only central archive, although the archiving methods for fieldwork performed by other institutions were not entirely standardised. IA SAS currently maintains $\underline{\text { CEANS }}$ and provides basic spatial data and metadata for the general public. IA SAS is also developing an internal information system ISAU, which consists of multiple databases. These include 29,760 records related to fieldwork (the register of documentation, register of AI SAS fieldwork and other historical records of fieldwork and finds from 1951-2002) as well as databases of photo-documentation, archaeological finds, digital versions of documentation, and maps from fieldwork activities of IA SAS (Bednár et al. 2018; Lečbychová and Kosarová 2018; Blažová 2019). External researchers can access the fieldwork documentation after approval from the director of IA SAS. In the case of living authors, their consent is also necessary. The ISAU database is linked to the MUSEION database, which is focused on the recording and management of data concerning portable finds registered in the IA SAS (Bednár et al. 2018).

\section{Archaeological Monument Fund}

Archaeological sites that are classified as national cultural monuments are subject to a specific monument protection, focused on the prevention of danger, damage or destruction, and on the maintenance of good condition and appropriate ways of presentation. These sites usually have preserved historical geomorphology (hillforts, mounds) and the protection aspires to preserve their authenticity for the future. At present, there are 302 archaeological sites classified as national cultural monuments and another 2084 national cultural monuments include archaeology (castles, sacral and urban architecture, etc.). Hundreds of archaeological sites with a higher degree of protection are also included in monument reservations and monument zones.

MB SR maintains a register of the monument fund, which consists of national cultural monuments, monument reservations and monument zones. At present, this non-spatial database (the Automated Information System for Monument Protection) is used only for state administration. It is partially accessible to the general public through the MB SR 
website. In PAMIS (Section 5), this database will be transformed to include the spatial features. As of today, more than 5100 of about 11,600 monument objects are already digitised.

Selected objects from the Monument fund, such as UNESCO sites, European cultural heritage sites, monument reservations, monument zones, and national cultural monuments are being digitised under the Digitization of Cultural Heritage project. The project is supported by the European Regional Development Fund under the Operational Programme Information Society. In the realisation phase of the project (2012-15), 1858 monument objects were digitised by professional surveyors, digitisers or by outside contractors. The whole process is archived, including raw data (photographs, geodetic survey), archive materials, sketches, other records as well as the presentation outputs. At present, the project is in the sustainability phase (2016-21). Once the project is finalised, at least 2358 monument objects will be digitally documented. Further information can be found in Brunčák et al. (2015) and Kravjanská (2018).

Within the project, 3D models, orthogonal views, panoramas and drawings are created for research purposes. The data processing and archiving is secured by a DMZ server with a capacity of $100 \mathrm{~Tb}$, which does not meet current technological needs. MB SR provides these data on demand to students, professional public, monument administrators and owners, and other institutions for non-commercial use, free of charge. Part of the data is accessible to the general public via Sketchfab and Slovakiana.sk.

A significant part of the digital outputs is also stored in the Central Data Archive (CDA), which was created in 2012-15 by the University Library in Bratislava as a long-term reliable digital data storage for the Operational Programme 'Information Society' (OPIS). CDA follows international and national legislation as well as good practices. The capacity of this repository is 25 petabytes; at present, about $20 \%$ is used

(Tomková 2019). MB SR uses the CDA to store about 33Tb of data and plans to use this storage also for archaeological data created outside the OPIS framework.

\section{The Monument Information System PAMIS}

The Monument Information System (PAMIS) aims to address some issues mentioned in this article. PAMIS is financed by the Cohesion Fund and the European Regional Development Fund. The implementation phase of the project $(06 / 2019-06 / 2022)$ will be followed by a sustainability phase (07/2022-07/2029).

The primary goal of PAMIS is the development of an integrated information system with several modules focused on the digitisation of the monuments fund registers and the monument protection, namely the knowledge agenda, state administration, presentation layer, support applications and integration layer. PAMIS will be a joint information system of the monument fund and archaeological registers.

In archaeology, PAMIS is the starting point for organised data management. As a special part of the system, PAMIS should also implement CEANS to link MB SR and IA SAS. Non-spatial registers rely on creating a complex central database of archaeological fieldwork documentation, which will be linked to the respective spatial layers. 


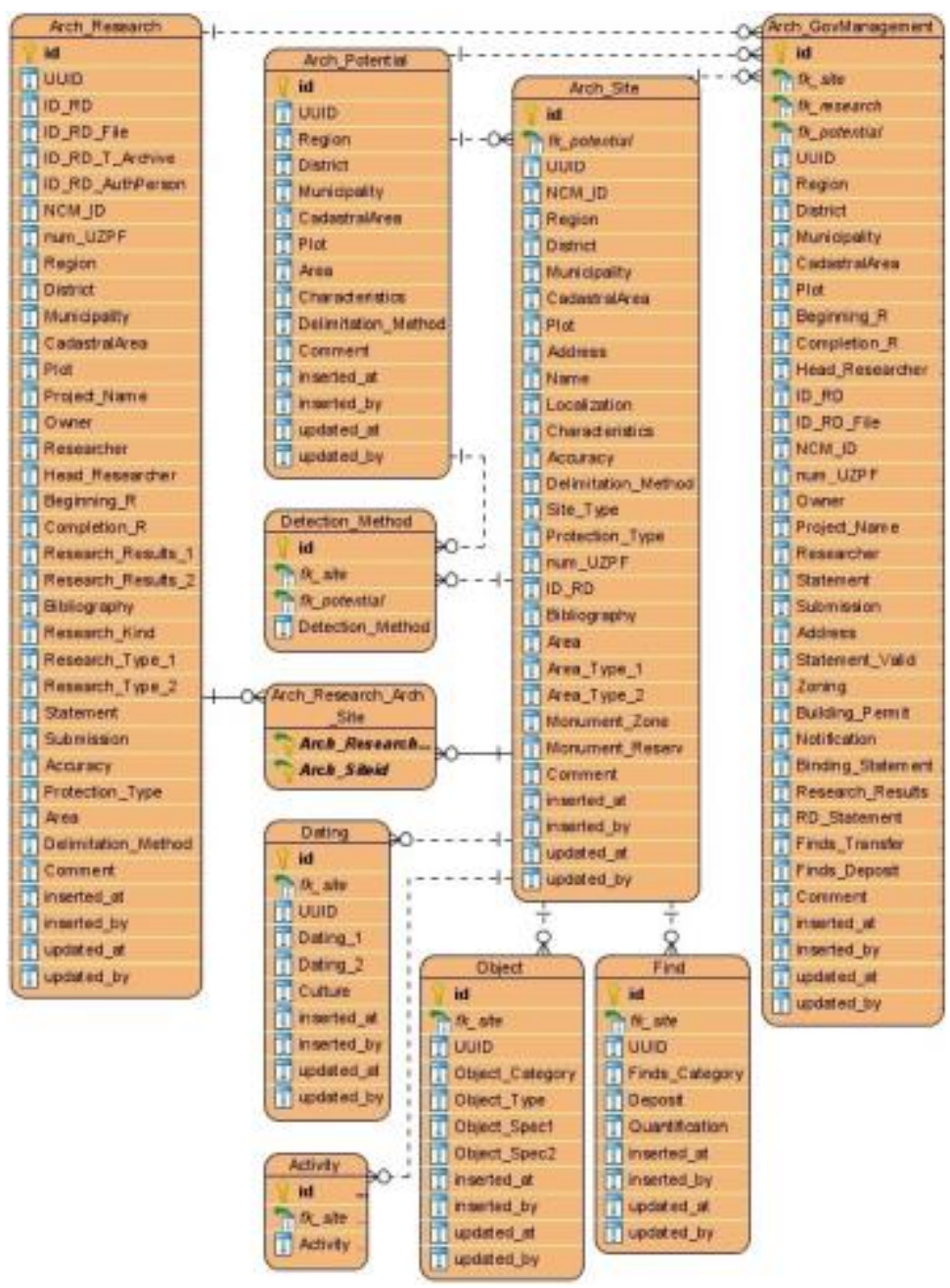

Figure 1: Data structure of archaeological layers of PAMIS

Archaeological layers are designed as separate components with their own data structure (Figure 1) integrated with the rest of the PAMIS components. There are four archaeological spatial layers: sites, research, potential and state administration. In the archaeological site layer (Figure 2), one polygon represents one general type of an archaeological area (e.g. settlement, mining area, burial grounds). Archaeological site polygons can be created: i) based on the background data, such as historical maps, satellite imagery, terrain visualisations, or ii) based on the archaeological fieldwork. The relationship between fieldwork and sites is M:N, i.e. multiple sites can be defined from one fieldwork activity and multiple fieldwork activities can be conducted at one site. The archaeological potential layer represents arbitrary polygons that define the expected extent of an archaeological site, such as i) the terrain morphology assumed to be anthropogenic, ii) areas where archaeological finds can be expected (e.g. hillsides of hillforts), or iii) the expected, but not yet confirmed extent of a site derived from archaeological fieldwork. The state administration layer will provide the link between various authorities during and after the archaeological fieldwork, starting from the construction permit issued to the developer, up to information about the transfer and deposition of archaeological finds. 


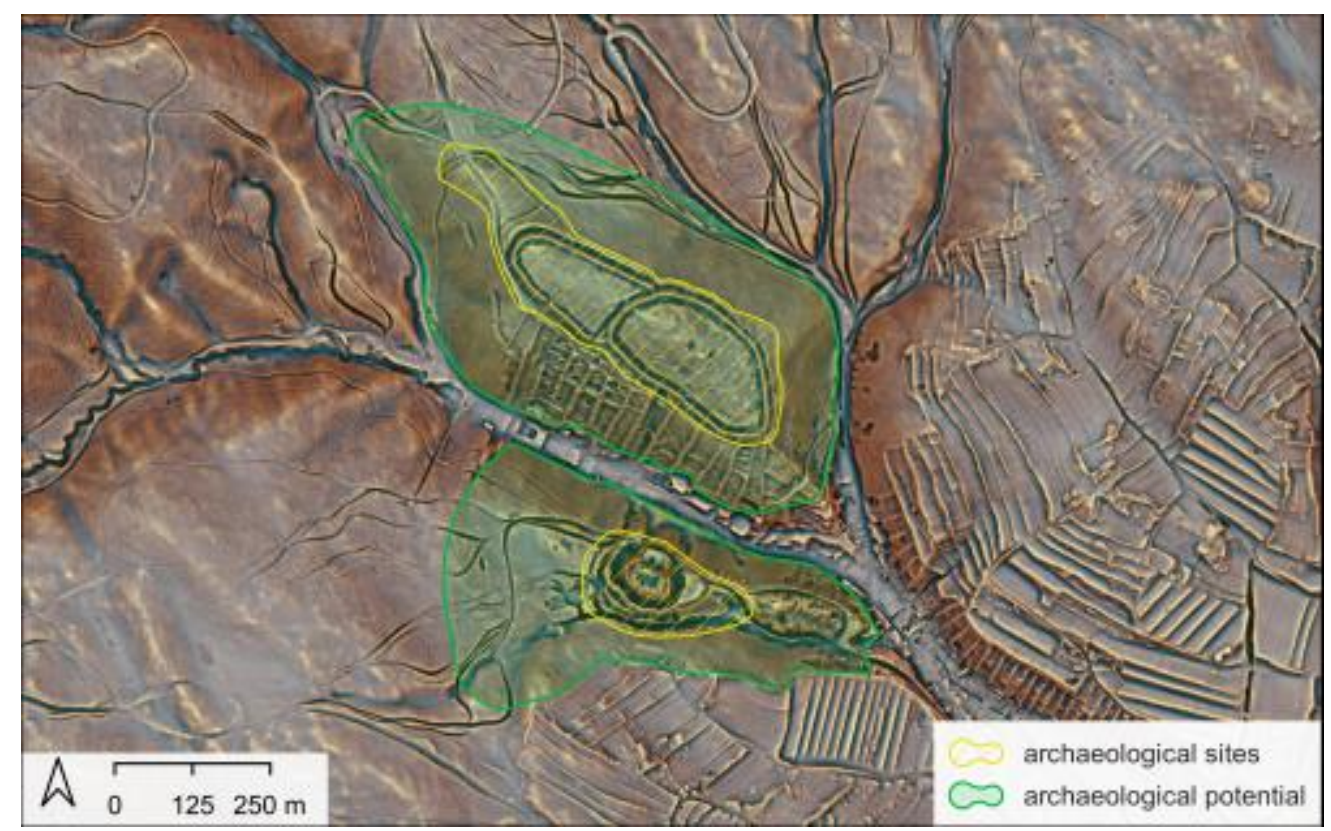

Figure 2: An example of archaeological sites and potential in archaeological layers of PAMIS - Hillfort Neštich (north), Biely Kameň castle (south), cadastre: Svätý Jur. ALS data source: GCCA

In future, the data from PAMIS will be provided to the state and public administrations, professionals in the field and the general public via an online platform, with levels of access depending on pre-defined user's roles. Fieldwork documentation is expected to be made accessible at least to the professionals in the field. However, the technical details and legal aspects of this issue are still being discussed.

MB SR is using raster visualisations of data from aerial laser scanning (ALS) at $1 \mathrm{~m}$ resolution (Figure 2) provided by $\mathrm{T}$. Lieskovský (Slovak University of Technology in Bratislava). These visualisations rely on modified methods (Canuto et al. 2018; Kokalj and Hesse 2017; Kokalj and Somrak 2019) and enhance the topography by capturing multiple topographic properties at once, e.g. curvature (blue-green for convex, yellow for concave features), intensity changes (red), or openness to the sky (contrast). MB SR also uses the ALS data to create 3D models of archaeological sites that are published on Sketchfab.

Apart from the obvious benefits, the free accessibility of ALS data to the general public is also associated with some risks. Both the state administration and illegal looters are trying to extract new information about archaeological sites. Therefore, MB SR and the Slovak University in Technology are working together on a crowdsourcing project for licensed archaeologists. After registration, they would gain access to the visualisation layers and ALS interpretation datasets. In exchange, they will be obliged to submit their findings and survey reports back to MB SR, who will ensure protection of the sites and finds.

\section{Conclusions and Discussion}

Digital cultural heritage management in Slovakia is, after 15 years of its existence, still at the beginning of its journey. There are several projects in progress with promising 
results, such as the digitisation of records in the Monument Archive, the Digital Monument Fund, or the implementation of geographic information systems to data management in PAMIS.

However, there is a lot of work ahead of us. Archives of MB SR contain more than 6000 archaeological fieldwork reports. These records are being managed in nine different types of registers, either by MB SR or the eight Regional Monument Boards. Also, there are no rules defined for archiving the original analogue or digital fieldwork records. Apart from the framework provided by PAMIS to address this issue, it is also necessary to simplify the overall administrative agenda related to archaeological fieldwork reports to make the processes more efficient.

In the past, a lot of data concerning archaeological and cultural heritage were kept inside the institutions that managed them. Therefore, we are glad that PAMIS aspires to share some of the data with field professionals and with the general public. However, this goal requires tidying of the registers and datasets, and also legislative changes, mainly regarding the submission of fieldwork reports. Copyright issues may also negatively affect the amount of digital data made available.

\section{Acknowledgements}

The Monuments information system (PAMIS) is financed by the Cohesion Fund and the European Regional Development Fund.

The Digitization of Cultural Heritage project was supported by the European Regional Development Fund under the Operational Programme Information Society.

Tibor Lieskovský was supported by the project VEGA 1/0468/20. The ALS data were kindly provided by the Geodesy, Cartography and Cadastre Authority of the Slovak Republic.

ALS data processing in 2018 and 2019 was conducted with the financial support of the Ministry of Culture of the Slovak Republic within the priority project of the Monuments Board of the Slovak Republic.

We would like to thank D. Novák, M. Kuna and D. Křivánková (Institute of Archaeology of the Czech Academy of Sciences in Prague) for consultations and discussions about the archaeological databases and layers of PAMIS.

Act No. 49/2002 Z.z. of 19 December 2001 on the protection of monuments and historic sites, as amended. https://ar.unesco.org/sites/default/files/sk actprotecthistoricmontsites2001 en gtof.pdf

Bednár, P., Blažová, E. and Ruttkay, M. 2018 'Databases and Information Systems in the Archaeological Institute of the SAS' in D. Novák (ed) Computer Applications in Archaeology 17/2018, Abstract book. 34. 
Blažová, E. 2019 'Základné informácie o možnostiach a výstupoch Informačného systému Archeologického ústavu SAV', Zborník Slovenského národného múzea, Archeológia, Supplementum 12, 239-41.

Brunčák, P., Haličková, J., Sučíková, A. and Kravjanská, I. 2015 'Digitálny pamiatkový fond Slovenskej republiky', Informačné technológie a knižnice 2015(4), 3040. https://itlib.cvtisr.sk/buxus/docs/30 digitalny.pdf

Canuto, M.A., Estrada-Belli, F., Garrison, T.G., Houston, S.D. Acuña, M.J., Kováč, M., Marken, D., Nondédéo, P., Auld-Thomas, L., Castanet, C., Chatelain, D., Chiriboga, C.R., Drápela, T., Lieskovský, T., Tokovinine, A., Velasquez, A., Fernández-Díaz, J.C. and Shrestha, R. 2018 'Ancient lowland Maya complexity as revealed by airborne laser scanning of northern Guatemala', Science 361(6409),

17. https://doi.org/10.1126/science.aau0137

Kmet'ová, P. and Bisták, P. 2020 'Otvorenie Depozitára archeologických nálezov Pamiatkového úradu SR'. http://www.pamiatky.sk/sk/page/otvorenie-depozitaraarcheologickych-nalezov-pamiatkoveho-uradu-sr [Last accessed: 1 March 2020].

Kokalj, Ž. and Hesse, R. 2017 Airborne Laser Scanning Raster Data Visualization. A Guide to Good Practice. ISBN: 9789612549848 https://doi.org/10.3986/9789612549848

Kokalj, Ž. and Somrak, M. 2019 'Why not a single image? Combining visualizations to facilitate fieldwork and on-screen mapping', Remote Sensing 11(7),

747. https://doi.org/10.3390/rs11070747

Kravjanská, I. 2018 'Digitalizácia drevených chrámov v slovenskej časti Karpatského oblúka', Monument Revue 7(1), 72-

80. https://www.pamiatky.sk/Content/Data/File/ARCHIV/MR 2018-1.pdf

Lečbychová, O. and Kosarová, L. 2018 'Zveřejňování dat z archeologických archivů situace v některých zemí Evropské unie. Odkud jdeme a kam směřujeme', Zprávy památkové péče 78(1), 45-53.

Mařík, J. and Prášek, K. 2014 'Management of archaeological excavations and control in the Czech and Slovak Republic' in V.M. van der Haas and P.A.C. Schut (eds) The Valleta Convention: Twenty Years After - Benefits, Problems, Challenges, EAC Occasional Paper No. 9, Brussels. 113-18.

Ruttkay, M., Bednár, P., Cheben, I., and Kovár, B. 2016 'Archaeological research in the Slovak Republic - positives and negatives' in P. Florjanowicz (ed) When Valleta meets Faro. The reality of European archaeology in the 21st century, EAC Occasional Paper No. 11. 53-58.

Tomková, K. 2019 'Certifikácia a audit v Centrálnom dátovom archíve', Knihovna plus 1 https://knihovnaplus.nkp.cz/archiv/2019-01/historie-a-soucasnost/certifikacia-aaudit-v-centralnom-datovom-archive [Last accessed: 1 March 2020]. 